\title{
Analisis Efisiensi Teknis dan Ekonomi Penggunaan Faktor-Faktor Produksi Pada Usahatani Jagung Hibrida di Kelompok Tani Sidomulyo 01 Kecamatan Sukolilo Kabupaten Pati
}

\author{
Augustina Rosarinda Yudhi Tungga Dewi, Siswanto I. Santoso dan Edy Prasetyo ${ }^{1}$ \\ Program Studi S1 Agribisnis Fakultas Peternakan dan Pertanian \\ Universitas Diponegoro, Semarang \\ Email : rosarindayudhi24@gmail.com
}

\begin{abstract}
ABSTRAK
Tujuan penelitian adalah menganalisis efisiensi teknis dan ekonomi usahatani tanaman jagung hibrida di Desa Porang - Paring, Kecamatan Sukolilo, Kabupaten Pati. Responden dalam penelitian ini adalah petani jagung hibrida anggota Kelompok Tani Sido Mulyo 01 yang tinggal di Desa Porang - Paring. Metode penelitian menggunakan survei, penentuan responden menggunakan metode Simple Random Sampling dengan jumlah responden sebanyak 57 petani dari populasi sebanyak 133 petani jagung hibrida. Analisis efisien teknis dan ekonomi menggunakan regresi linier berganda dengan fungsi produksi model CobbDouglas. Hasil penelitian menunjukkan nilai signifikansi sebesar 0,000 bahwa seluruh faktor produksi secara serempak berpengaruh nyata terhadap produksi jagung hibrida, dan secara parsial faktor produksi luas lahan, benih, pestisida memiliki nilai signifikansi < 0,005 sehingga faktor produksi berpengaruh nyata terhadap produksi jagung hibrida, sedangkan faktor produksi pupuk urea, pupuk phonska, pupuk organik dan tenaga kerja memiliki nilai signifikansi > 0,005 sehingga tidak berpengaruh nyata. Berdasarkan hasil analisis efisiensi teknis, faktor produksi produksi luas lahan sebesar 0,638; benih sebesar 0,125; pupuk urea sebesar 0,021; pupuk phonska sebesar 0,014; pupuk organik sebesar $-0,029$; pestisida sebesar 0,214 dan tenaga kerja sebesar 0,025. Faktor produksi tidak mencapai efisiensi teknis dengan nilai elatisitas produksi berada dibawah angka satu. Hasil analisis efisiensi ekonomi, faktor produksi luas lahan sebesar 3,234 ; benih sebesar 3,059 ; pupuk phonska sebesar 1,016 dan pestisida sebesar 7,327 nilai berada diatas angka 1 sehingga penggunaan faktor produksi belum efisien. Nilai efisiensi ekonomi faktor produksi pupuk urea sebesar 0,976 ; pupuk organik sebesar $-6,516$ dan tenaga kerja sebesar 0,162 nilai berada dibawah angka 1 sehingga tidak mencapai efisiensi ekonomi.
\end{abstract}

Kata Kunci : efisiensi, ekonomi, faktor-faktor produksi, jagung hibrida.

Technical and Economic Efficiency Analysis of The Use of Production Factors on Hybrid Maize Farming in Sido Mulyo 01 Farmer's Group in Distric Sukolilo Pati Regency

\section{ABSTRACT}

This study aims to analyze the technical and economic efficiency of hybrid maize plantation in Porang - Paring Village, Sukolilo, Pati. The respondents participated in this study ate the hybrid maize farmers who are also the members of SidoMulyo 01 Farmer Group in Porang - Paring Village. This study implements a survey as the research method, while the respondents are determined by using Simple Random Sampling method with the number of respodents is as many as 57 farmers out of 133 hybrid maize farmers. The study analyzes the technical and economic efficiency by employing multiple linear regressions with Cobb-Douglas production function. The result of research shows that the significance value of 0,000 that all factors of production simultaneously have a significant effect on hybrid corn production, and partially factor of land area, seed, pesticide has significance value $<0,005$ so that production factor have significant effect to hybrid corn production, while fertilizer production factor urea, phonska fertilizer, organic fertilizer and labor have significance value> 0.005 so no real effect. Based on the results of technical efficiency analysis, production factors of production of land area of 0.638; seeds of 0.125; urea fertilizer by 0,021; phonska fertilizer by 0,014; organic fertilizer equal to -0,029; pesticide of 0.214 and labor of 0.025 . The production factor does not achieve technical efficiency with the value of production elatisitas below the number one. Result of analysis of economic efficiency, land area production factor 3,234; seeds of 3,059; phonska fertilizer amounted to 1.016 and pesticide of 7.327 value 
Dewi, et al. 2018

is above the number 1 so that the use of production factor has not been efficient. The economic efficiency value of urea fertilizer production factor is 0,976; organic fertilizer equal to $-6,516$ and labor equal to 0,162 value is under number 1 so do not reach economic efficiency.

Keywords : efficiency,economy, production factors, hybrid maize.

\section{PENDAHULUAN}

Indonesia merupakan negara agraris dengan sektor perekonomian utama dititikberatkan pada sektor pertanian. Sektor pertanian memegang peranan penting dan seharusnya menjadi penggerak dari kegiatan perekonomian negara. Hal ini kemudian menjadikan sektor pertanian sebagai pasar yang potensial bagi produk-produk dalam negeri baik untuk barang produksi maupun barang konsumsi, terutama produk yang dihasilkan oleh subsektor tanaman bahan makanan.

Tanaman jagung termasuk subsektor tanaman pangan dalam sektor pertanian. Tanaman ini memiliki fungsi yang potensial sebagai bahan subtitusi beras karena memiliki kandungan karbohidrat, kalori dan protein. Jagung dapat tumbuh pada berbagai macam tanah, terlebih lagi tanaman jagung merupakan tanaman yang cocok ditanam di musim kemarau karena tidak membutuhkan banyak air. Produksi jagung dapat ditingkatkan dengan pemakaian varietas unggul baik jagung yang bersari bebas maupun hibrida. Jagung hibrida dapat memberikan hasil yang lebih tinggi bila dibanding dengan jagung yang bersari bebas. Varietas jagung hibrida adalah generasi pertama hasil persilangan antara dua varietas bersari bebas. Varietas bersari bebas merupakan varietas yang sudah homogen dan sudah mendapatkan sertifikat (Antara, 2010).

Berdasarkan data Badan Pusat Statistik Provinsi Jawa Tengah (2016) luas panen , produktivitas dan produksi jagung yang ada di Provinsi Jawa Tengah dari tahun 20132015 terus mengalami peningkatan. Jumlah rata-rata produksi jagung di Provinsi Jawa Tengah tahun 2013-2015 sebanyak $3.064 .939,31$ ton dengan rata-rata luas panen 537.656 ha dan rata-rata produktivitas 56,99 kw/ha. Berdasarkan data Dinas Pertanian Kabupaten Pati (2016) jumlah rata-rata produksi jagung di Kabupaten Pati tahun 2013-2015 sebanyak 120.171 ton dengan rata-rata luas panen 19.579 ha dan rata-rata produktivitas $61 \mathrm{kw} / \mathrm{ha}$. Kecamatan Sukolilo merupakan salah satu kecamatan di Kabupaten Pati yang memiliki luas panen dan luas lahan terbesar yaitu 8,749 ha luas tanam dan luas panen sebesar 8,814 ha.

Usahatani jagung hibrida dijalankan dengan mengkombinasi beberapa faktor produksi sedemikian rupa sehingga dapat menghasilkan output yang dapat menghasilkan keuntungan. Produk-produk pertanian biasanya dihasilkan dari kombinasi faktor produksi berupa lahan, tenaga kerja dan kombinasi penggunaan modal (pupuk, benih dan pestisida) (Soekartawi, 2003). Tersedianya sarana atau faktor produksi tidak selamanya memberikan produksi yang dapat menguntungkan petani. Sering ditemukan penggunaan faktor produksi oleh petani tidak lagi sesuai dengan kebutuhan skala petani.

Petani dapat memperoleh keuntungan maksimal dengan cara mengadakan pemilihan penggunaan faktor produksi secara tepat, mengkombinasikan secara optimal dan efisien. Namun pada kenyataannya masih banyak petani yang belum memahami bagaimana faktor produksi tersebut digunakan secara efisien. Solusi yang dapat dilakukan petani adalah dengan memperhatikan efisiensi usahatani yang sedang dijalankan, maka dapat 
memaksimalkan produksi sehingga pendapatan petani juga meningkat.

Penelitian ini bertujuan untuk Menganalisis pengaruh penggunaan faktor faktor produksi yang meliputi : luas lahan, benih, pupuk, pestisida dan tenaga kerja terhadap produksi usahatani jagung hibrida, menganalisis efisiensi teknis dan ekonomi penggunaan faktor-faktor produksi usahatani jagung hibrida di Kelompok Tani Sido Mulyo 01.

\section{METODE PENELITIAN}

\section{Waktu dan Lokasi Penelitian}

Penelitian ini dilaksanakan pada bulan Desember 2017 sampai dengan Januari 2018 di Desa Porang - Paring, Kecamatan Sukolilo, Kabupaten Pati. Desa Porang Paring dipilih secara purposive dikarenakan sebagai penghasil jagung hibrida terbesar di Kabupaten Pati.

\section{Metode Penelitian}

Penelitian dilakukan dengan metode survei dan pengamatan secara langsung. Wawancara dilakukan dengan menggunakan alat bantu kuesioner mengenai identitas responden dan usahatani jagung hibrida. Data yang dikumpulkan berupa data primer yang diperoleh dengan wawancara secara langsung dengan responden. Data sekunder diperoleh dari instansi - instansi terkait seperti Badan Pusat Statistika dan Dinas Pertanian Pati. Data primer meliputi data jumlah produksi jagung hibrida, data jumlah penggunaan luas lahan, data jumlah penggunaan pupuk, data jumlah penggunaan pestisida, data jumlah penggunaan benih dan data jumlah penggunaan tenaga kerja dalam satu kali musim tanam dan data harga faktor - faktor produksi yang digunakan oleh petani. Data Sekunder meliputi peta topografi, penggunaan luas lahan, luas wilayah dan produksi jagung di tingkat kabupaten.

\section{Metode Pengambilan Sampel}

Pengambilan sampel responden dengan menggunakan metode simple random sampling. Total petani di Kelompok Tani Sido Mulyo 01 adalah 133 petani. Perhitungan sampel responden menggunakan metode Slovin. Berdasarkan perhitungan menggunakan rumus Slovin, ukuran sampel minimal yang digunakan dalam penelitian ini adalah 57 petani jagumg hibrida. Rumus Slovin yang digunakan yakni :

$\mathrm{n}=\frac{\mathrm{N}}{1+\mathrm{Ne}^{2}}$

$$
\mathrm{n}=\frac{133}{1+133(0,1)^{2}}
$$

\section{Metode Analisis Data}

Analisis efisiensi teknis dan ekonomi menggunakan fungsi produksi model CobbDouglas dengan mencari koefisien regresi dari setiap faktor produksi. Faktor - faktor produksi yang diduga mempengaruhi produksi jagung hibrida adalah luas lahan $(x 1)$, benih $(x 2)$, pupuk urea $(x 3)$, pupuk phonska (x4), pupuk organik (x5), pestisida $(x 6)$, dan jumlah tenaga kerja $(x 7)$.

Bentuk persamaan umum fungsi produksi Cobb-Douglas adalah sebagai

berikut :

$\mathrm{Y}=\mathrm{b}_{0} \mathrm{X}_{1}^{\mathrm{b} 1} \cdot \mathrm{X}_{2}^{\mathrm{b} 2} \cdot \mathrm{X}_{3}^{\mathrm{b} 3} \cdot \mathrm{X}_{4}^{\mathrm{b} 4} \cdot \mathrm{X}_{5}^{\mathrm{b} 5} \cdot \mathrm{X}_{6}^{\mathrm{b} 6} \cdot \mathrm{X}_{7}^{\mathrm{b} 7} \cdot \mathrm{e}^{\mathrm{u}}$

Model persamaan data produksi dan faktor produksi diubah menjadi bentuk persamaan linier melalui transformasi logaritma natiral agar koefisien regresi dapat dihitung sebagai berikut :

$$
\begin{gathered}
\operatorname{Ln} Y=\operatorname{Ln} b_{0}+b_{1} \operatorname{Ln} X_{1}+b_{2} \operatorname{Ln} X_{2}+b_{3} \operatorname{Ln} X_{3} \\
+b_{4} \operatorname{Ln} X_{4}+b_{5} \operatorname{Ln} X_{5}+ \\
\quad b_{6} \operatorname{Ln} X_{6}+b_{7} \operatorname{Ln} X_{7}+u \operatorname{LNe}
\end{gathered}
$$

Keterangan :

LnY = produksi jagung hibrida $(\mathrm{kg} / \mathrm{MTH})$

$\operatorname{LnX}_{1}=$ luas lahan (ha)

$\operatorname{LnX}_{2}=$ benih $(\mathrm{kg} / \mathrm{MTH})$

$\mathrm{LnX}_{3}=$ pupuk urea $(\mathrm{kg} / \mathrm{MTH})$

$\mathrm{LnX}_{4}=$ pupuk phonska $(\mathrm{kg} / \mathrm{MTH})$

$\operatorname{LnX}_{5}=$ pupuk organik $(\mathrm{kg} / \mathrm{MTH})$

$\operatorname{LnX}_{6}=$ pestisida (liter/MTH)

$\mathrm{LnX}_{7}=$ tenaga kerja $(\mathrm{HOK} / \mathrm{MTH})$

bo $=$ konstanta 
$\mathrm{bi} \quad=$ koefisien regresi yang merupakan

elastisitas produksi $(i=1,2,3,4,5,6,7)$

$\varepsilon \quad=$ bilangan natural $(e=2,17182882)$

$\mathrm{u}=$ eror/kesalahan

Persamaan yang telah diperoleh dilanjutkan dengan uji asumsi klasik dan uji analisis regresi linier berganda. Uji asumsi klasik terdiri dari uji multikolinearitas, uji heterokedastisitas dan uji autokorelasi. Sedangkan uji analisis regresi linier berganda yang terdiri dari uji koefisien determinasi, uji $F$ ( serempak dan uji t (parsial).

Persamaan analisis efisiensi teknis dengan fungsi model Cobb-Douglas (Ekowati et al., 2014) dapat dihitung dengan menggunakan rumus elastisitas produksi, sebagai berikut:

$$
E T=\frac{M P P x i}{A P P x i}=\frac{B x i \cdot \frac{y i}{x i} \cdot x i}{y i}=B x i
$$

Keterangan :

$E T=$ Efisiensi Teknis

MPP = Produk Marjinal

APP $=$ Produk Rata - rata

Kriteria:

- Jika ET = 1 maka faktor produksi sudah efisien secara teknis.

- Jika ET > 1 maka faktor produksi belum efisien secara teknis.

- Jika ET < 1 maka faktor produksi tidak efisien secara teknis.

Perhitungan analisis efisiensi

ekonomi dihitung dengan menggunakan persamaan sebagai berikut (Ekowati et al., 2014) :

$$
\mathrm{EE}=\frac{\mathrm{NPMxi}}{\mathrm{BKMxi}}=\frac{\mathrm{Bxi}-\frac{\bar{y}}{\bar{x}}-\mathrm{P}_{\mathrm{y}}}{\mathrm{BKMxi}}
$$

$$
\begin{aligned}
& \text { Keterangan : } \\
& \text { EE } \quad=\text { Efisiensi Ekonomi } \\
& \text { NPM }=\text { Nilai Produktivitas Marjinal } \\
& \text { BKM = Biaya Korbanan Marjinal }
\end{aligned}
$$

Kriteria:
- Jika EE = 1 maka faktor produksi sudah efisien secara ekonomis.

- Jika EE > 1 maka faktor produksi belum efisien secara ekonomis.

- Jika $\mathrm{EE}<1$ maka faktor produksi tidak efisien secara ekonomis.

\section{HASIL DAN PEMBAHASAN}

Tanaman Jagung

Tanaman jagung banyak ditanam di ladang yang berhawa sedang maupun panas. Sebagai bahan pangan, jagung memiliki kandungan karbohidrat yang tinggi. Jagung juga mengandung gula, kalium, asam jagung, dan minyak lemak. Rambut jagung mengandung minyak lemak, dammar, gula, asam maisenat, dan garam-garam mineral. Jagung biasa diolah menjadi tepung jagung atau maizena (Suroso, 2006). Sistematika tanaman jagung menurut Effendi (1998) adalah sebagai berikut :
Kingdom : Plantae
Divisio : Spermatophyta
Sub Divisio : Angiospermae
Classis : Monocotyledone
Ordo : Graminae

Familia: Graminaceae

Genus : Zea

Species $\quad$ : Zea mays $L$

Varietas jagung hibrida yaitu varietas yang benihnya tidak dapat diambil dari pertanaman sebelumnya. Setiap pertanaman jagung hibrida harus diganti dengan benih jagung yang baru, karena jika benih ditanam berulang-ulang, maka akan terjadi pemecahan sifat induknya dan produksinya menurun (Syukur dan Aziz, 2013).

\section{Gambaran Umum Daerah Penelitian}

Kecamatan Sukolilo merupakan salah satu kecamatan di Kabupaten Pati Provinsi Jawa Tengah. Kecamatan Sukolilo memiliki luas wilayah sebesar $158,74 \mathrm{~km}^{2}$ yang secara administratif terbagi ke dalam 16 
desa. Mempunyai luas wilayah 15.874 ha yang terdiri dari lahan sawah seluas 7.253 ha, lahan bukan sawa seluas 4.439 ha dan lahan bukan pertanian seluas 4.182 ha. Secara Geografis Desa Porang Paring merupakan salah satu desa yang berada di Kecamatan Sukolilo Kabupaten Pati. Desa susukan memiliki luas wilayah sebesar 719,5 ha / km2 dengan 30 ha lahan tadah hujan dan 689,5 ha lahan bukan sawah/ Tegalan, tinggi tempat $40 \mathrm{~m}-158 \mathrm{dpl}$ dengan topografi datar, bergelombang dan berbukitbukit, suhu udara rata-rata $28^{\circ} \mathrm{C}-36^{\circ} \mathrm{C}$.

\section{Faktor yang Mempengaruhi Produksi} Jagung Hibrida

Berdasarkan Tabel 1, faktor produksi yang digunakan petani jagung hibrida meliputi lahan, benih, pupuk urea, pupuk phonska, pupuk organik, pestisida dan tenaga kerja. Rata-rata produksi usahatani jagung hibrida di Kelompok Tani Sido Mulyo 01 Desa Porang-paring pada adalah 13.151 $\mathrm{kg} /$ periode musim tanam.

Uji model regresi menggunakan uji koefisien determinasi, uji $F$, uji $T$ dan uji asumsi klasik untuk mengetahui pengaruh faktor input terhadap produksi usahatani jagung hibrida. Uji asumsi klasik meliputi uji multikolinearitas, heterokedastisitas dan autokorelasi, sehingga memperoleh hasil uji regresi yang tertera pada Tabel 2 .

Berdasarkan hasil uji regresi berdasarkan koefisien Standarized pada Tabel 2, faktor produksi yang berpengaruh secara parsial terhadap variabel terikat adalah lahan $(\mathrm{x} 1)$, benih $(\mathrm{x} 2)$ dan pestisida (x5) dengan nilai signifikansi 0,05 dengan nilai elastisitas produksi di bawah satu sehingga faktor produksi tidak efisien secara teknis. Nilai signifikansi lahan (x1) sebesar 0,000 , nilai signifikansi benih $(x 2)$ sebesar 0,010 , nilai signifikansi pestisida (x6) sebesar 0,000. Hal ini sesuai pendapat Hartono (2008) yang menyatakan bahwa nilai signifikansi $<0,05$ menunjukkan variabel independen secara parsial mempunyai pengaruh yang signifikan terhadap variabel dependen.

\section{Analisis Efisiensi Teknis dan Ekonomi}

Analisis efisiensi teknis usahatani jagung hibrida di Kelompok Tani Sido Mulyo 01, Desa Porang - Paring , Kecamatan Sukolilo, Kabupaten Pati diperoleh dengan menelaah nilai elastisitas produksi (b) yang berasal dari output fungsi produksi model Cob-Douglas. Hasil analisis efisiensi teknis dapat dilihat pada Tabel 3. Analisis efisiensi teknis usahatani jagung hibrida di Kelompok Tani Sido Mulyo 01, Desa Porang - Paring , Kecamatan Sukolilo, Kabupaten Pati diperoleh dengan cara menghitung Nilai Produk Marginal (NPM) dengan Biaya Korbanan Marjinal (BKM). Nilai Elastisitas produksi model Cobb-Douglas juga digunakan dalam perhitungan efisiensi ekonomi. Rumus menghitung NPM menurut Soekartawi (2003) adalah hasil kali dari harga produk (Py) dengan produk marginal (PM). Hasil analisis efisiensi ekonomi dapat dilihat bahwa penggunaan faktor produksi lahan, benih, pupuk phonska dan pestisida memiliki nilai efisiensi lebih dari 1 , sehingga penggunaan faktor produksi belum efisien. Hasil analaisis efisiensi ekonomi pupuk urea, pupuk orgaanik dan tenaga kerja memiliki nilai efisiensi kurang dari 1 , sehingga penggunaan faktor produksi tidak efisien.

\section{a. Faktor Produksi Lahan}

Berdasarkan hasil analisis dapat dilihat bahwa efisiensi teknis penggunaan lahan sebesar 0,638 dimana nilai berada dibawah angka satu sehingga penggunaan lahan tidak efisien secara teknis dan penggunaan luas lahan perlu dikurangi. Nilai efisiensi teknis bernilai positif sehingga penggunaan lahan berada pada daerah II (rasional). Efisiensi ekonomi penggunaan lahan sebesar 3,234 sehingga efisiensi ekonomi penggunaan lahan belum tercapai dan nilai Biaya Korbanan Marjinal (BKM) sebesar Rp $6.000 .000,00$ per ha per tahun yang merupakan rerata biaya sewa lahan 
pertanian di desa porang - paring. Nilai Produk Marjinal (NPM) sebesar Rp 19.405.909,00. Efisiensi Ekonomi dapat tercapai dengan meningkatkan nilai Biaya Korbanan Marjinal (BKM) menjadi sebanding dengan Nilai Produk Marjinal (NPM). Mufrianti dan Anton (2014) menyatakan bahwa lahan merupakan faktor produksi utama yang juga menjadi penentu dari pengaruh faktor produksi dalam sektor pertanian. Secara umum, semakin luas lahan yang digunakan untuk usahatani, maka semakin besar jumlah produksi yang dihasilkan oleh lahan tersebut.

\section{b. Faktor Produksi Benih}

Berdasarkan hasil analisis dapat dilihat bahwa efisiensi teknis penggunaan benih sebesar 0,125 dimana nilai berada dibawah angka 1 sehingga penggunaan benih tidak efisien secara teknis dan penggunaan benih perlu dikurangi. Nilai efisiensi teknis bernilai positif sehingga penggunaan benih berada pada daerah II (rasional). Efisiensi ekonomi penggunaan benih sebesar 3,059 sehingga efisiensi ekonomi penggunaan benih belum tercapai dan nilai Biaya Korbanan Marjinal (BKM) benih sebesar Rp 75.000,00 per musim tanam yang merupakan rata-rata harga benih. Nilai Produk Marjinal (NPM) sebesar Rp 229.443,00. Nilai Biaya Korbanan Majinal (BKM) perlu ditingkatkan guna tercapainya efisiensi ekonomi, sehingga sebanding dengan Nilai Produk Marjinal (NPM) benih. Suzana et al., (2011) menyatakan bahwa Benih merupakan faktor penting pada suatu tanaman karena benih merupakan awal kehidupan dari tanaman. Benih harus memiliki mutu yang baik agar mampu menghasilkan tanaman yang berproduksi maksimum.

\section{c. Faktor Produksi Pupuk Urea}

Berdasarkan hasil analisis dapat dilihat bahwa efisiensi teknis penggunaan pupuk urea sebesar 0,021 dimana nilai berada dibawah angka 1 sehingga penggunaan pupuk urea tidak efisien secara teknis dan penggunaan pupuk urea perlu dikurangi. Nilai efisiensi teknis bernilai positif sehingga penggunaan pupuk urea berada pada daerah II (rasional). Efisiensi ekonomi penggunaan pupuk urea sebesar 0,976 sehingga efisiensi ekonomi penggunaan pupuk urea tidak tercapai dan nilai Biaya Korbanan Marjinal (BKM) pupuk urea sebesar Rp 1.800,00 per musim tanam yang merupakan rata - rata harga pupuk urea. Nilai Produk Marjinal (NPM) sebesar Rp 1756,00. Efisiensi Ekonomi penggunaan pupuk urea dapat tercapai dengan mengurangi Biaya Korbanan Marjinal (BKM) pupuk urea sehingga sebanding dengan Nilai Produk Marjinal (NPM) pupuk urea. Triyono et al., (2013) menyatakan bahwa efisiensi penggunaan pupuk $\mathrm{N}$ dilakukan dengan pemberian sesuai dengan rekomendasi. Pupuk Urea yang berlebihan akan menghambat penyerapan unsur hara dan tanaman akan mudah terserang hama dan penyakit.

\section{d. Faktor Produksi Pupuk Phonska}

Berdasarkan hasil analisis dapat dilihat bahwa efisiensi teknis penggunaan pupuk phonska sebesar 0,014 dimana nilai berada dibawah angka 1 sehingga penggunaan pupuk phonska tidak efisien secara teknis dan penggunaan pupuk phonska perlu dikurangi. Nilai efisiensi teknis bernilai positif sehingga penggunaan pupuk phonska berada pada daerah II (rasional). Efisiensi ekonomi penggunaan pupuk phonska sebesar 1,016 sehingga efisiensi ekonomi penggunaan pupuk phonska belom tercapai dan nilai Biaya Korbanan Marjinal (BKM) pupuk phonska sebesar Rp 2.300,00 per musim tanam yang merupakan rata rata harga pupuk phonska. Nilai Produk Marjinal (NPM) sebesar Rp 2.336. Efisiensi Ekonomi penggunaan pupuk phonska dapat tercapai dengan meningkatkan Biaya Korbanan Marjinal (BKM) pupuk phonska sehingga sebanding dengan Nilai Produk 
Marjinal (NPM) pupuk phonska. Marsono dan Sigit (2001) menyatakan bahwa Pupuk phonska berfungsi untuk memacu pertumbuhan vegetatif dan generatif, menguatkan batang tanaman sehingga tidak mudah roboh, memeprlancar proses pembentukan gula dan pati, memacu pertumbuhan akar tanaman, membuat tanaman lebih hijau dan sehat, meningkatkan daya tahan tanaman terhadap kekeringan dan memacu pembentukan bungan dan buah.

\section{e. Faktor Produksi Pupuk Organik}

Berdasarkan hasil analisis dapat dilihat bahwa efisiensi teknis penggunaan pupuk organik sebesar -0,029 dimana nilai berada dibawah angka 1 sehingga penggunaan pupuk organik tidak efisien secara teknis dan penggunaan pupuk organik perlu dikurangi. Nilai efisiensi teknis bernilai negative sehingga penggunaan pupuk organik berada pada daerah III (irasional). Efisiensi ekonomi penggunaan pupuk organik sebesar $-6,516$ sehingga efisiensi ekonomi penggunaan pupuk organik belom tercapai dan nilai Biaya Korbanan Marjinal (BKM) pupuk organic sebesar Rp 500,00 per musim tanam yang merupakan rata - rata harga pupuk organik. Nilai Produk Marjinal (NPM) sebesar Rp 3.258,00. Efisiensi Ekonomi penggunaan pupuk phonska dapat tercapai dengan mengurangi Biaya Korbanan Marjinal (BKM) pupuk organiksehingga sebanding dengan Nilai Produk Marjinal (NPM) pupuk organik. Supartha et al., (2012) menyatakan bahwa pupuk organik merupakan pupuk hasil dekomposisi bahan - bahan organik yang diurai oleh mikroba, yang hasil akhirnya dapat menyediakan unsur hara yang dibutuhkan tanaman untuk pertumbuhan dan perkembangan tanaman.

\section{f. Faktor Produksi Pestisida}

Berdasarkan hasil analisis dapat dilihat bahwa efisiensi teknis penggunaan pestisida sebesar 0,214 dimana nilai berada dibawah angka 1 sehingga penggunaan pestisida tidak efisien secara teknis dan penggunaan pestisida perlu dikurangi. Nilai efisiensi teknis bernilai positif sehingga penggunaan pestisida berada pada daerah II (rasional). Efisiensi ekonomi penggunaan pestisida sebesar 7,327 sehingga efisiensi ekonomi penggunaan pestisida belom tercapai dan nilai Biaya Korbanan Marjinal (BKM) pestisida sebesar Rp 65.000,00 per musim tanam yang merupakan rata - rata biaya pestisida per liter. Nilai Produk Marjinal (NPM) sebesar Rp 476.233,00. Nilai Biaya Korbanan Majinal (BKM) perlu ditingkatkan guna tercapainya efisiensi ekonomi, sehingga sebanding dengan Nilai Produk Marjinal (NPM) pestisida. Purwono (2007) menyatakan bahwa pestisida sangat dibutuhkan petani untuk mencegah serta membasmi hama dan penyakit tanaman yang dibudidayakan. Pestisida dapat menjadi kerugian bagi petani jika terjadi kesalahan pemakaian baik dari cara maupun komposisi yang diaplikasikan ke tanaman.

\section{g. Faktor Produksi Tenaga Kerja}

Berdasarkan hasil analisis dapat dilihat bahwa efisiensi teknis penggunaan tenaga kerja sebesar 0,025 dimana nilai berada dibawah angka 1 sehingga penggunaan tenaga kerja tidak efisien secara teknis dan penggunaan tenaga kerja perlu dikurangi. Nilai efisiensi teknis bernilai positif sehingga penggunaan tenaga kerja berada pada daerah II (rasional). Efisiensi ekonomi penggunaan tenaga kerja sebesar 0,162 sehingga efisiensi ekonomi penggunaan tenaga kerja belom tercapai dan nilai Biaya Korbanan Marjinal (BKM) tenaga kerja sebesar Rp 87.500,00 yakni rata-rata biaya tenaga kerja per HOK. Nilai Produk Marjinal (NPM) tenaga kerja sebesar Rp 14.189,00. Biaya Korbanan Marjinal (BKM) perlu dikurangi agar tercapainya efisiensi ekonomi faktor produksi tenaga kerja. Simanjuntak (1998) menyatakan bahwa Tenaga kerja merupakan orang yang sanggup untuk bekerja. Seseorang yang termasuk sebagai 
tenaga kerja adalah seseorang yang mengurus rumah tangga, sekolah, yang mencari kerja, atau sedang bekerja dengan usia 14-60 tahun.

\section{SIMPULAN \& SARAN}

Penggunaan faktor-faktor produksi luas lahan, benih, pupuk urea, pupuk phonska, pupuk organik, pestisida dan tenaga kerja secara serempak berpengaruh terhadap produksi jagung hibrida dengan hasil siginifikansi sebesar 0,000 dan secara parsial penggunaan faktor-faktor produksi luas lahan, benih, pestisida bepengaruh nyata terhadap produksi jagung hibrida dengan nilai signifikansi $<0,005$, sedangkan faktor produksi pupuk urea, pupuk phonska, pupuk organik dan tenaga kerja tidak berpengaruh dengan nilai signifikansi $>0,005$.

Berdasarkan hasil analisis efisiensi teknis, faktor produksi produksi luas lahan sebesar 0,638 ; benih sebesar 0,125 ; pupuk urea sebesar 0,021 ; pupuk phonska sebesar 0,014 ; pupuk organik sebesar 0,029 ; pestisida sebesar 0,214 dan tenaga kerja sebesar 0,025. Faktor produksi tidak mencapai efisiensi teknis dengan nilai elatisitas produksi berada dibawah angka satu. Hasil analisis efisiensi ekonomi, faktor produksi luas lahan sebesar 3,234 ; benih sebesar 3,059 ; pupuk phonska sebesar 1,016 dan pestisida sebesar 7,327 nilai berada diatas angka 1 sehingga penggunaan faktor produksi belum efisien. Nilai efisiensi ekonomi faktor produksi pupuk urea sebesar 0,976 ; pupuk organik sebesar -6,516 dan tenaga kerja sebesar 0,162 nilai berada dibawah angka 1 sehingga tidak mencapai efisiensi ekonomi.

Petani disarankan untuk menerapkan pedoman usahatani tanaman jagung hibrida secara lengkap untuk memperoleh hasil produksi optimal. Petani mampu meningkatkan efisiensi teknis dengan cara mengurangi penggunaan faktor produksi luas lahan, benih, pupuk urea, pupuk phonska, pupuk organik, pestisida dan tenaga kerja.Petani mampu meningkatkan efisiensi ekonomi dengan cara mengurangi penggunaan faktor produksi luas lahan, benih, pupuk urea, pupuk phonska, pupuk organik, pestisida dan tenaga kerja. 
Agrisaintifika

Jurnal Ilmu-Ilmu Pertanian

Vol. 2, No. 1, 2018

Tabel 1. Faktor Produksi Usahatani Tanaman Jagung Hibrida

\begin{tabular}{lrrr}
\hline \multicolumn{1}{c}{ Variabel } & Rata-rata & \multicolumn{1}{c}{ Minimum } & \multicolumn{1}{c}{ Maksimum } \\
\hline Lahan (ha/MTH) & 1,64 & 0,69 & 2,82 \\
Benih (kg/MTH) & 27,58 & 8,5 & 45,7 \\
Pupuk Urea (kg/MTH) & 619,77 & 200 & 1.000 \\
Pupuk Phonska (kg/MTH) & 376,40 & 127 & 771 \\
Pupuk Organik (kg/MTH) & 562,44 & 181 & 2.012 \\
Pestisida (liter/MTH) & 22,54 & 8,1 & 38,6 \\
Tenaga Kerja (HOK/MTH) & 92,67 & 58,4 & 226,3 \\
\hline
\end{tabular}

Sumber : Data Primer Penelitian, 2018

Tabel 2. Hasil Uji Regresi berdasarkan Koefisien Standarized

\begin{tabular}{lrrc}
\hline Model & $\mathrm{B}$ & \multicolumn{1}{c}{$\mathrm{t}$} & \multicolumn{1}{c}{ Sig. } \\
\hline Constant & 1.107 & 10,910 & 0,000 \\
Lahan (LnX1) & 0,624 & 6,668 & $0,000^{* *}$ \\
Benih (LnX2) & 0,110 & 2,686 & $0,010^{*}$ \\
Pupuk Urea (LnX3) & 0,017 & 1,266 & 0,212 \\
Pupuk Phonska (LnX4) & 0,008 & 1,266 & 0,211 \\
Pupuk Organik (LnX5) & $-0,016$ & $-1,657$ & 0,104 \\
Pestisida (LnX6) & 0,206 & 3,997 & $0,000^{* *}$ \\
Tenaga Kerja (LnX7) & 0,026 & 1,940 & 0,058 \\
\hline$R^{2}=0,838$ & & \\
$\mathrm{~F}_{\text {hitung }}=74,675 \mathrm{~F}_{\text {tabel }}=2,20(\alpha=5 \%)$ & & & \\
\hline
\end{tabular}

Sumber : Data Primer Penelitian, 2018

Keterangan : * Variabel berpengaruh nyata Sig $\leq 0,05$

** Variabel sangat berpengaruh nyata Sig $\leq 0,01$

Tabel 3. Analisis Efisiensi Teknis dan Ekonomi Usahatani Tanaman Jagung Hibrida di Kelompok Tani Sido Mulyo 01, Desa Porang - Paring, Kecamatan Sukolilo, Kabupaten Pati

\begin{tabular}{lcc}
\hline \multicolumn{1}{c}{ Variabel } & Efisiensi Teknis & Efisiensi Ekonomi \\
\hline Lahan & 0,638 & 3,234 \\
Benih & 0,125 & 3,059 \\
Pupuk Urea & 0,021 & 0,976 \\
Pupuk Phonska & 0,014 & 1,016 \\
Pupuk Organik & $-0,029$ & $-6,516$ \\
Pestisida & 0,214 & 7,327 \\
Tenaga Kerja & 0,025 & 0,162 \\
\hline
\end{tabular}

Sumber : Data Primer Penelitian, 2018 
Agrisaintifika

Jurnal Ilmu-Ilmu Pertanian

Vol. 2, No. 1, 2018

\section{DAFTAR PUSTAKA}

Antara, M. 2010. Analisis Produksi dan Komparatif Antara Usahatani Jagung Hibrida Dengan Non Hibrida Di Kecamatan Palolo Kabupaten Sigi. J Agroland 17 (1) : 56-62.

Badan Pusat Statistik Provinsi Jawa Tengah. 2016. Jawa Tengah Dalam Angka Tahun 2016. Badan Pusat Statistik, Semarang.

Dinas Pertanian Kabupaten Pati. 2016. Data Produksi Tanaman Jagung , Luas Lahan Jagung dan Produktivitas Jagung. Dinas Pertanian, Pati

Effendi, S. 1995. Bercocok Tanam Jagung. Jasa Guna, Jakarta.

Ekowati, T., D. Sumarjono, H. Setiyawan, dan E. Prasetyo. 2014. Buku Ajar Usahatani. UPT Undip Press, Semarang.

Hartono, 2008. SPSS 16,0 Analisis Data Statistikadan Penelitian. Pustaka Pelajar, Yogyakarta.

Marsono dan P. Sigit. 2001. Pupuk Akar, Jenis dan Aplikasinya. Penebar Swadaya, Jakarta.

Mufrianti, F., dan Anton, F. 2014. Analisis faktor produksi dan efisiensi alokatif usahatani bayam (Amarathus Sp) di Kota Bengkulu. J Agrisep 15 (1): 3137.

Purwono. 2007. Budidaya 8 Jenis Tanaman Pangan Unggul. Penebar Swadaya, Jakarta.
Soekartawi. 2003. Teori Ekonomi Produksi dengan Pokok Bahasan Analisis Cobb-Douglas. Grafindo Persada, Jakarta.

Simanjuntak, P, J. 1998. Pengantar Ekonomi Sumber Daya Manusia. Penerbit FE UI (Fakultas Ekonomi Universitas Indonesia), Jakarta.

Supartha, I, N, Y., Wijana, G., Adnyana, G, M. 2012. Aplikasi jenis pupuk organik pada tanaman padi sistem pertanian organik. J. Agroekoteknologi Tropika 1 (1) : 98106.

Suroso. 2006. Analisis Pendapatan dan Faktor-Faktor yang Mempengaruhi Usahatani Jagung. Skripsi. Departemen Ilmu-IImu Sosial Ekonomi Pertanian. Fakultas Pertanian. Institut Pertaniaan Bogor.

Syukur, M dan Azis Rifianto. 2013. Jagung Manis. Penebar Swadaya, Jakarta.

Suzana, B. O. L., Joachim, N. K. D., dan Sudarti. 2011. Analisis efisiensi penggunaan faktor-faktor produksi pada usahatani padi sawah di desa Mupoyo Utara Kecamatan Dumogo Utara Kabupaten Bolaang Mongondow. J. ASE 7 (1): 38-47

Triyono, A., Purwanto., Budiyono. 2013. Efisiensi penggunaan pupuk $\mathrm{N}$ untuk pengurangan kehilangan nitrat pada lahan pertanian. Prosiding Seminar Nasional Pengelolaan Sumber Daya Alam dan Lingkungan 2013. ISBN9786002-179001-1-2: 526-53 